\title{
MAP Kinase-Activated Protein Kinase 5
}

National Cancer Institute

\section{Source}

National Cancer Institute. MAP Kinase-Activated Protein Kinase 5. NCI Thesaurus. Code C113083.

MAP kinase-activated protein kinase 5 (473 aa, $\sim 54 \mathrm{kDa}$ ) is encoded by the human MAPKAPK5 gene. This protein is involved in serine/threonine phosphorylation, tumor growth suppression and signaling regulation. 